\title{
The Impact of Socio-scientific Issue Discussions on Student Environmentalism
}

\author{
Hsin-Hui Wang ${ }^{1}$, Zuway-R Hong ${ }^{2}$, Shu-Chiu Liu ${ }^{1}$, Huann-Shyang Lin ${ }^{1,3^{*}}$ \\ ${ }^{1}$ Center for General Education, National Sun Yat-Sen University, 70 Lien Hai Road, Kaohsiung 804 TAIWAN R.O.C. \\ ${ }^{2}$ Institute of Education, National Sun Yat-Sen University, 70 Lien Hai Road, Kaohsiung 804 TAIWAN R.O.C. \\ ${ }^{3}$ Faculty of Education and Arts, Australian Catholic University, 1100 Nudgee Road, Banyo, QLD, AUSTRALIA
}

Received 16 May 2018 • Revised 23 August 2018 • Accepted 26 August 2018

\begin{abstract}
A one group pretest-posttest design of study was used to investigate the impact of Socio-Scientific Issue (SSI) discussion on college students' awareness of and selfefficacy toward environmental issues, responsibility for sustainable development, and environment-related activities. Thirty-nine students with different majors from a comprehensive university participated in the semester-long SSI intervention study. The teaching intervention is focused on empowering students to develop reflection and argumentation through watching contextual videos of current environmental issues, justifying personal standing position and achieving group consensus, and evaluating and critiquing peer group's presentations. After 17 weeks of SSI discussion and argumentation, the quantitative results revealed that students' awareness of environmental issues, responsibility for sustainable development, self-efficacy for environmental issues, and environment-related activities had been significantly promoted. Additional qualitative findings indicate that the SSI discussion has gained the leverage of changing students' decision-making and standing position on environmental issues from emphasising economic development to supporting environmental protection and sustainability. Overall, this study provides empirical evidences and original insights about the effect of SSI discussion on environmental education through highlighting the importance of engaging students in practicing reflection and argumentation.
\end{abstract}

Keywords: environmental awareness and responsibility, environment-related activity, reflection, self-efficacy, socio-scientific issue

\section{INTRODUCTION}

One of the significant features of environmental and sustainability education (ESE) is to empower individual citizens to develop critical thinking and competence in taking part actively in democratic processes on environmental and sustainability issues (Huckle, 2008; Læssøe, 2010). During the democratic process, not only are diverse viewpoints and opinions encouraged and respected, but they become the targets of critical examination, reflection, evaluation, and discussion. Hopefully, consensus and wise decision are expected to be made through the process. Therefore, developing effective strategies of learning opportunities for the aforementioned competencies have become a critical issue for environmental and sustainability education. Surprisingly, limited attention has been paid to the issue of empowering students to develop reflection and argumentation. Advocators in the field have posited their concern and the need for future research studies (e.g., Gadotti, 2008; Wilks \& Harris, 2016).

In today's society, we are facing a number of issues being discussed in public media requiring us to make decisions, many of which are related to controversial environmental problems and scientific concepts (e.g., climate

(c) 2018 by the authors; licensee Modestum Ltd., UK. This article is an open access article distributed under the terms and conditions of the Creative Commons Attribution License (http://creativecommons.org/licenses/by/4.0/).

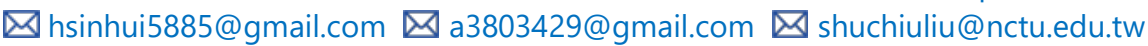




\section{Contribution of this paper to the literature}

- While existing literature has documented the importance of reflection, evaluation, argumentation, and decision-making competencies, limited attention has been paid on classroom-based research in environmental and sustainability education.

- The use of video-based contextual Socio-Scientific Issue (SSI) discussion in classroom teaching provides fresh insights into the innovative curricular design and teaching practice.

- This study provides empirical evidence about the effect of SSI discussion on student environmentalism and highlights the importance of engaging students in practicing reflection and argumentation.

change, global warming, loss of biodiversity, cloning biotechnology, mobile phone electromagnetic radiation and human health). These issues are not only inclined to have multiple plausible solutions (Sadler \& Dawson, 2012; Yu \& Yore, 2013) but are also influenced by social, cultural, and political norms and public opinions. Researchers refer to these issues as socio-scientific issues (SSI) (Sadler \& Donnelly, 2006; Venville \& Dawson, 2010). The core feature of deliberative dialogue in SSI discussion is the opportunity to reason, to criticise, and to justify (i.e., to argue). The ability to argue in an effective manner such as providing evidence-based arguments or strong rebuttals becomes a central component of scientific literacy (Zeidler et al., 2003). As it is quite challenging for typical students or citizens to make informed and socially responsible decisions about complex socio-scientific and environmental issues, some researchers assert that the controversial and contextual characteristic of SSI has potential to make classroom teaching practices challenging, motivating, and useful for developing students' evaluation, reflection, argumentation, communication, and decision-making competencies (Belova et al., 2015; Lin et al., 2012; Sadler, 2004).

While conventional teaching strategies used by many teachers emphasise science as a body of knowledge (Aikenhead, 1994), proponents of science, technology, society and environment (STSE) education place science in a larger social, cultural and political context. For example, Pedretti's (2003) STSE education framework included the components of sustainable development, decision-making, ethics and moral reasoning, personal and political dimensions, critical social reconsideration, action, and nature of science emphasis. Pedretti further asserted that one way of achieving the challenging goals offered by STSE advocates was through the exploration of SSI. Additional existing research studies also documented the importance of emphasising and embedding multidisciplinary content in SSI argumentation. For instance, using a model termed SEE-SEP (i.e., covering sociology/culture, economy, environment/ecology, science, ethics/morality, and policy), Christenson et al. (2014) analysed secondary students' justifications on four SSI, including global warming, genetically modified organism, nuclear power, and consumer consumption. They recommended that explicitly making students connect interdisciplinary resources to their SSI learning in school will likely enhance students' skills to develop good-quality argumentation during SSI discussions. Along similar lines, the environmental issues of the extinction of species, pollution levels, the consumption of non-renewable resources, and unfair distribution of earth's natural resources have been major concerns for educators who focused on propagating education for the sake of sustainable development. Some frontier researchers have recommended utilising interdisciplinary learning strategies and developed innovative structures of engaging students in deliberative SSI discussions and collaborative projects (e.g., Blum et al., 2013; de Haan, 2006) to promote students' problem solving capacity.

Wilks and Harris (2016) indicated the importance of helping young people recognise the links between environmental issues and the logical pathways that lead from environmental responsibility to environment-related activities. The understanding of the complexities of environmental information and the recognition of interconnectedness about environmental issues and activities formulate the overarching cognitive framework which can support activities to address concerns of current and developing environmental problems (Morelli, 2011). We hypothesized that it is more likely for students to develop the above understanding and recognition when they are engaged in open discussion and critical reflection on local and international environmental issues. The purposes of this study are to explore the effectiveness of open discussion in a classroom on local and international socio-scientific issues (SSI) and identify how student environmental viewpoints, environment-related activities, and argumentation can be changed in the learning process.

\section{Theoretical Background of the Study}

This study aimed to investigate the potential impact of open SSI discussion in a classroom on students' environmental viewpoints and environment-related activities. The design of teaching intervention for this study was guided by the integration of transactional perspective (Dewey \& Bentley, 1949), participatory approach (Huckle, 2008), and the concept of reflection. In the book of "knowing and the known", Dewey's transactional perspective posits that humans interact with learning environment and that meaning emerges in the process of doing. In addition, the process of meaning-making is eventually a social process which is consistent with the 
process of knowledge construction depicted by the science educators advocating the principle of social constructivism (Driver et al., 1996). Participatory approach encourages learners to critically examine a variety of views on different questions and problems relating the future of our world while the learners are engaged in open discussion or debate (Öhman \& Öhman, 2013). The basic intention of participatory approach is to empower learners to develop action competence through democratic procedures of argumentation on sustainability issues (Læssøe, 2010). When students involved in a discussion try to examine or evaluate a variety of views, the reflective ability plays a critical role in empowering them to evaluate peers' comments and integrate appropriate content knowledge into their arguments. Gresch et al. (2017) concluded that students' reflective ability can be developed in welldesigned learning activities. Therefore, it is reasonable to assume that the integration of transactional perspective and participatory approach, along with providing opportunities for reflection in a teaching intervention, could be beneficial to the development of students' cognitive framework and better understanding of complex environmental issues.

\section{Significance of Assessing and Developing Students' Environmental Viewpoints and Environment-related Activities}

In the past 30 years, dozens of studies have focused on the measurements of environmental attitudes and the identification of how environmental attitudes are related with or contribute to environmental behaviour (Boubonari et al., 2013; Schultz, 2011). Most of the above studies used the original New Environmental Paradigm (Dunlap \& Van Liere, 1978) or its revised version, New Ecological Paradigm (Dunlap, Van Liere, Mertig, \& Jones, 2000), to assess the level of student understanding of environmental issues (i.e., environmentalism). After reviewing these studies, Schultz (2011) posited that in addition to the assessment of how much a person is pro-environment, there is a need to assess environmental perspective and action. Along similar lines, scholars assert that environmental education should focus on the development of action competence, including reflection, critical thinking, and participation (Englund et al., 2008; Huckle, 2008; McNeill \& Vaughn, 2012). In the process of developing action competence, students are encouraged to strengthen their capability of reflection and take a stand while involving themselves with other learners in responsible actions and counter-actions for a more humane world (Schnack, 2000). In order to improve the quality of teaching action competence, Mogensen and Schnack (2010) recommend that educators must concentrate on improving the strategy of teaching and learning to empower students not only to be informed and aware, but also to act sustainably in the face of environmental issues. Eventually, students are expected to be able to adopt informed decisions and act to solve environmental problems through democratic procedure. Therefore, the development of this action competence requires teaching approaches that foster participation, reflection, critical thinking, and collaboration with peer learners. The above literature provides additional insights into the design of teaching intervention for this study and echoes the study's theoretical background of participatory approach, transactional perspective, and the concept of reflection.

\section{The Use of Socio-scientific Issues for Discussion}

Empirical evidence has shown that the integration of SSI in classroom teaching is capable of promoting the quality level of students' arguments and position changes (i.e., switching viewpoints or taking a different stand after discussion) (Lin et al., 2012; Yu \& Yore, 2013) and participants' perceptions of self-efficacy (Yahaya et al., 2015).

Advocators of SSI suggest that there remains an urgent need for classroom-based research to identify the relative impact of factors affecting the quality of instruction and the achievement of desired outcomes using SSI (Sadler \& Dawson, 2012). As we searched for literature related to SSI in major environmental education journals, surprisingly, there was only one article using the SSI topic of 'climate change and costs' to investigate students' reasoning on nature and economic development (Sternäng \& Lundholm, 2012). At the end of their article, Sternäng and Lundholm concluded that 'Environmental education typically emphasises private share environmentalism... i.e., what an individual can do to reduce negative effects on the environment. However, effective actions when dealing with environmental problems are collective..., therefore, students should be given opportunities to discuss the societal and global sphere and analyze environmental problems as public issues' (p. 433). The review of above literature inspired us to integrate SSI in classroom teaching as a way of intervention in a college level of environmental education course. Additionally, in order to relate SSI discussions to student daily life, we purposively selected contextualised videos as part of the teaching intervention. The following research questions guided this study:

1. What are the impacts of video-based contextual SSI discussions on students' awareness and self-efficacy of environmental issues, responsibility for sustainable development, and actual environment-related activities?

2. How are student SSI arguments varied and changed over time? 


\section{METHODOLOGY}

This study was conducted in the context of an undergraduate course-Socio-Scientific Issues - with 'Our Island' as an example. The participants and setting, teaching intervention, instrument, and data analysis are described as follows:

\section{Participants and Setting}

The study was conducted in a one-group pretest/posttest design with the participation of 39 students from one highly ranked public comprehensive university in Kaohsiung City, Southern Taiwan. The university attracted diverse and high achieving students from all over the country. These students were enrolled in a general-liberal elective course which was attended 110 minutes every week lasting for 17 weeks. Taught by the corresponding author, the course was comprised of 10 specific controversial local and international environmental issues and intended to provide learning opportunities of science communication and argumentation. The 39 participants (29 males and 10 females) in the study were undergraduate students from colleges of art and humanities, sciences, engineering, management, marine science, and social science. Although the convenient sample size was small, its diversity of students' majors and backgrounds constituted a typical class in the university, allowing for small group discussion and more student-teacher interactions. The participants responded to the Environmental Questionnaire at the beginning (Week 1) and end (Week 17) of this study. In the weekly class meetings, the students were divided into 10 groups with each composed of 3-4 students. They were encouraged to work cooperatively to complete group worksheet of the SSI questions, to support their arguments with reasons, and reflect on and respond to the other group students' critiques and comments. At the end of this class, each group needed to finish a report about environmental issues. The most reported environmental issue is "air pollution". Others include stray dogs, excess land reclamation, dengue fever.

\section{Teaching Intervention}

In order to provide video-based contextual Socio-Scientific Issues (SSI) that were relevant to the participants, we collaborated with Taiwan Public Television Service and used the videos of its award winning programmeOur Island - as part of the intervention for the study. The producer of the programme was invited into the class as a guest speaker, addressing the goal, motivation, and significant stories of making the programme videos. Most of the programme videos were related with current environmental issues that happened in Taiwan. Each original video was about one hour long. Because of time limitation, it was reorganised and adjusted into 15-20 minutes for teaching intervention. The Programme for International Student Assessment (PISA) (OECD, 2009, 2016) converged the environmental issues into 9 topics (e.g., air pollution, clearing of forests for other land use, and nuclear waste) to measure the level of students' awareness of environmental issues. Following the work of OECD (2006; 2016), Table 1 shows the environment-related topics of videos that we selected. These videos integrated with the environmental challenges due to the ever-changing development of science and technology strongly connected to students' daily life. Along with each of the videos, we also developed a learning sheet for students to explain their standing positions and arguments in the context of these controversial issues. The emphasis in argumentation about SSI was intended to promote students' understanding about the issues and their capability of making informed decisions for society. The weekly 110-minute SSI teaching intervention provided the following focused learning opportunities: (a) instructor's introduction and demonstration of related scientific concepts and knowledge (30minutes), (b) watching contextual video related to weekly topics (20 minutes), (c) reflecting and writing individual/group learning sheets (20 minutes), (d) making small group consensus (10 minutes), (e) sharing, critiquing, and discussing selected groups' presentations (30 minutes). 
Table 1. Weekly SSI topics, video titles, and learning sheet questions

Week Content

\begin{tabular}{|c|c|c|}
\hline \multirow{4}{*}{1} & SSI topics & Organic agriculture \\
\hline & video titles & Small-holder farmers' kindness to land \\
\hline & learning sheet questions & -- \\
\hline & corresponding issues in PISA & -- \\
\hline \multirow{4}{*}{2} & SSI topics & Using recycled paper \\
\hline & video titles & Tears of the rainforests \\
\hline & learning sheet questions & $\begin{array}{l}\text { Which of the following is more suitable for you when purchasing toilet paper? Please } \\
\text { describe your justification. (A) I will definitely choose recycled paper; (B) If I see recycled } \\
\text { paper, I will buy it; (C) I will buy the brand I am used to, or the cheapest one; (D) Others. }\end{array}$ \\
\hline & corresponding issues in PISA & Forest destruction \\
\hline 3 & Course was suspended once $f$ & r national holiday. \\
\hline \multirow{4}{*}{4} & SSI topics & Importing genetically modified food \\
\hline & $\underline{\text { video titles }}$ & Genetically modified crops \\
\hline & learning sheet questions & $\begin{array}{l}\text { If you were a staff member in the government Council of Agriculture, would you support } \\
\text { the law of permitting the import of genetically modified seeds if the product is clearly } \\
\text { labelled? What is your position? Please describe your justification. }\end{array}$ \\
\hline & corresponding issues in PISA & Use of genetically modified organisms \\
\hline \multirow{4}{*}{5} & SSI topics & Developing new site for nuclear waste disposal \\
\hline & video titles & Nuclear waste disposal in Dawu township \\
\hline & learning sheet questions & $\begin{array}{l}\text { If you are a citizen of Dawu township. Do you agree that the nuclear waste disposal is } \\
\text { located in your hometown? Please describe your justification. }\end{array}$ \\
\hline & corresponding issues in PISA & $\begin{array}{l}\text { Nuclear waste } \\
\text { Energy shortages }\end{array}$ \\
\hline \multirow{4}{*}{6} & SSI topics & Expanding Meiliwan resort hotel \\
\hline & video titles & Expanding Meiliwan resort hotel \\
\hline & learning sheet questions & $\begin{array}{l}\text { If you are a member of the environmental impact assessment committee, do you support } \\
\text { to expanding Meiliwan resort hotel? Please describe your justification. }\end{array}$ \\
\hline & corresponding issues in PISA & $\begin{array}{l}\text { Deforestation for other land use } \\
\text { Extinction of plants and animals }\end{array}$ \\
\hline \multirow{4}{*}{$7-8$} & SSI topics & Dioxins \& burning plastic \\
\hline & video titles & Toxic waste \\
\hline & learning sheet questions & -- \\
\hline & corresponding issues in PISA & $\begin{array}{l}\text { Air pollution } \\
\text { Greenhouse gases in the atmosphere } \\
\text { Acid rain }\end{array}$ \\
\hline 9 & Mid-term exam & \\
\hline \multirow{4}{*}{10} & SSI topics & Suspending the sixth naphtha cracking plant \\
\hline & video titles & Kuokuang petrochemical project \\
\hline & learning sheet questions & $\begin{array}{l}\text { Do you think the sixth naphtha cracking plant should stop working? } \\
\text { Please describe your justification. }\end{array}$ \\
\hline & corresponding issues in PISA & Air pollution \\
\hline 11 & Discourse & \\
\hline \multirow{4}{*}{$12-14$} & SSI topics & Marine biodiversity \\
\hline & video titles & Mackerel Festival \\
\hline & learning sheet questions & -- \\
\hline & corresponding issues in PISA & Extinction of plants and animals \\
\hline \multirow{4}{*}{15} & SSI topics & Animal ethics \\
\hline & video titles & Plead for the cattle \\
\hline & learning sheet questions & -- \\
\hline & corresponding issues in PISA & -- \\
\hline \multirow{4}{*}{16} & SSI topics & Water conservation \\
\hline & video titles & Water-saving policy \\
\hline & learning sheet questions & -- \\
\hline & corresponding issues in PISA & Water shortages \\
\hline 17 & Group reports & \\
\hline
\end{tabular}




\section{Instrument}

\section{Environmental questionnaire}

The environmental questionnaire included four dimensions derived from a part of the Chinese version of 'OECD Programme for International Student Assessment (PISA) 2006 and 2015 student questionnaire' which measured students' awareness and self-efficacy of environmental issues, responsibility for sustainable development, and environment-related activities. Although the target students of PISA were 15 years old, the environmental questionnaire was designed to elicit future citizens' attitudes and beliefs, instead of focusing on students' cognitive perception. Therefore, we considered that the questionnaire items were suitable for the use of college students.

The first dimension of the environmental questionnaire was awareness of environmental issues. The sample items were: 'How informed are you about the increase of greenhouse gases in the atmosphere?' and 'How informed are you about using of genetically modified organisms (GMO)?' The items were scored on a four-point scale, where ' 4 ' represented 'I am familiar with this and I would be able to explain this well' and ' 1 ' represented 'I have never heard of this.' Responses were summed, so that a higher score indicated higher awareness of environmental issues.

The $2^{\text {nd }}$ dimension was responsibility for sustainable development. The sample items were: 'It is important to carry out regular checks on the emissions from cars as a condition of their use' and 'I am in favour of having laws that regulate factory emissions even if this would increase the price of products.' The items were scored on a four-point scale, where ' 4 ' represented 'Strongly agree' and ' 1 represented 'Strongly disagree.' Responses were summed, so that a higher score represented better responsibility for sustainable development.

The $3^{\text {rd }}$ dimension was self-efficacy for environmental issues. The sample items were: 'Predict how changes to an environment will affect the survival of certain species' and 'Describe the role of antibiotics in the treatment of disease.' The items were scored on a four-point scale, where ' 4 ' represented 'I could do this easily' and ' 1 ' represented 'I couldn't do this.' Responses were summed, so that a higher score revealed higher self-efficacy for environmental issues.

The $4^{\text {th }}$ dimension was environment-related activities. The sample items were: 'How often do you watch TV programmes about science, environmental, or ecology?' and 'How often do you borrow or buy books on science, environmental or ecological topics?' Readers were reminded that these environment-related activities were called as either political engagement or consumer decisions in other references (de Haan, 2006). The items were scored on a four-point scale, where ' 4 ' represented 'Very often' and ' 1 ' represented 'Never or hardly ever.' Responses were summed, so that a higher score indicated more environment-related activities.

The environmental questionnaire had a high internal consistency (Cronbach's a $=.840)$. The internal consistency coefficients for the four dimensions were $.928, .976, .903$, and .893 , respectively. In addition, a confirmatory factor analysis (CFA) (Tabachnick \& Fidell, 2001) was conducted to evaluate how well the hypothesized models fitted the data of Taiwanese college student samples. All the factor loadings were significant (i.e. loadings range from 0.51 to 0.88), and the indexes of fit statistics indicated a good match for the data. Overall, the results showed that the model measured fitted the data quite well. These results based on an established measure revealed that the environmental questionnaire had appropriate validity and reliability.

\section{Learning sheet}

The weekly learning sheets were instructor-developed argumentation questions that encouraged students to provide justifications and arguments for their decision-making and standing position on a variety of environmentrelated SSI. In this study, the following five topics of individual learning sheets were used to analyze students' decision-making (or standing position) and arguments: Using recycled paper (2nd week); Importing genetically modified food ( $4^{\text {th }}$ week); Developing a new site for nuclear waste disposal (5 $5^{\text {th }}$ week); Expanding Meiliwan Resort Hotel (6 $6^{\text {th }}$ week); and Suspending the Sixth Naphtha Cracking Plant (10 th week).

\section{Data Analysis}

Both quantitative and qualitative data analyses were used in the study. Firstly, a paired t-test was performed to investigate responses to the pre- and post-test questionnaires across all dependent variables. Secondly, descriptive statistical analysis was used to describe the rank of awareness of environmental issues, responsibility for sustainable development, self-efficacy for environmental issues, and environment-related activities between pre- and post-tests. Finally, we used theme content analyses to analyse students' decision-making position and category of argument in weekly learning sheets. Some examples of coding student qualitative arguments are shown in Table 2. 
Table 2. Examples of student arguments and coding codes in SSI learning sheet

\begin{tabular}{|c|c|c|}
\hline Categories & Codes & Student arguments \\
\hline $\begin{array}{l}\text { A: } \\
\text { economic } \\
\text { development }\end{array}$ & $\begin{array}{l}\text { A-1 economic } \\
\text { benefits } \\
\text { A- } 2 \text { cost benefit }\end{array}$ & $\begin{array}{l}\text { - With a full liberalization of the genetically modified (GM) food market, the cheaper } \\
\text { price of GM foods would be expected.(A-1) } \\
\text { - Suspending the sixth naphtha cracking plant would result in social conflict and } \\
\text { detrimental effect on economic development. People need to bear the increase of } \\
\text { living costs. (A-2) }\end{array}$ \\
\hline $\begin{array}{l}\text { B: environmental } \\
\text { concern }\end{array}$ & $\begin{array}{l}\text { B-1 environment } \\
\text { B-2 ecology } \\
\text { B-3 energy } \\
\text { B-4 resources }\end{array}$ & $\begin{array}{l}\text { - The sixth naphtha cracking plant has produced a large amount of air pollutants. (B-1) } \\
\text { - Contaminated land may cause the extinction of endemic species. (B-2) } \\
\text { - Taiwan does not produce oil and relies on imports. (B-3) } \\
\text { - Crops will be polluted by the contaminated land. (B-4) }\end{array}$ \\
\hline
\end{tabular}

Table 3. Means and standard deviations of student awareness of environmental issues

\begin{tabular}{llccc}
\hline Item & Pre-test & Rank & Post-test & Rank \\
\hline The increase of greenhouse gases in the atmosphere & $3.18(.51)^{\mathrm{a}}$ & 1 & $3.41(.50)$ & 3 \\
\hline Air pollution & $3.15(.49)$ & 2 & $3.46(.51)$ & 1 \\
\hline Clearing of forests for other land use & $3.08(.48)$ & 3 & $3.38(.54)$ & 4 \\
\hline Acid rain & $3.05(.46)$ & 4 & $3.36(.54)$ & 5 \\
\hline Energy shortages & $3.03(.49)$ & 5 & $3.31(.52)$ & 7 \\
\hline Water shortages & $3.03(.49)$ & 5 & $3.26(.55)$ & 9 \\
\hline Nuclear waste & $2.97(.49)$ & 7 & $3.44(.50)$ & 2 \\
\hline Extinction of plants and animals & $2.97(.58)$ & 7 & $3.31(.52)$ & 7 \\
\hline Use of genetically modified organisms & $2.87(.62)$ & 9 & $3.36(.54)$ & 5 \\
\hline Overall & $\mathbf{2 7 . 3 3 ( 3 . 6 4 )}$ & & $\mathbf{3 0 . 2 8 ( 3 . 7 9 )}$ & \\
\hline a: Numbers in () are standard deviation & & &
\end{tabular}

In each learning sheet, two raters were trained to code students' arguments independently. The two raters' Kappa coefficients of agreement on the five learning sheets were .95, .82, 1, .73, and .78, respectively. According to Landis and Koch (1977), the levels of these coefficients ranged from 'substantial agreement' to 'almost perfect agreement.'

\section{RESULTS}

\section{What are the Impacts of Video-based Contextual SSI Discussions on Students' Environmentalism?}

\section{Awareness of environmental issues}

As shown in the method section, the environmental viewpoints investigated in this study included students' awareness of environmental issues, responsibility for sustainable development, and self-efficacy for environmental issues. For the results of the students' awareness of environmental issues, the pre- and post-test means and rankings of nine environmental issues ranging from greenhouse gases to energy shortages are shown in Table 3. It revealed that the three most informed environmental issues perceived by the participants were greenhouse gas increase, air pollution, and clearing of forests for other land use in the beginning of the study. After one semester of SSI discussion, the three most informed environmental issues changed to air pollution, nuclear waste, and greenhouse gas increase. Additional pair wise t-test for the comparison of the overall pre- and post-test means revealed that the undergraduate students have made significant progress on their awareness about the nine critical environmental issues $(t=-4.64, p<.001$, effect size $=.79)$.

\section{Responsibility for sustainable development}

In the assessment of responsibility for sustainable development, students were asked how they supported strategies and law enforcement of environmental protection. Table 4 shows that the three most critical strategies supported by the students for sustainable development were 'I am in favour of having laws that protect the habitats of endangered species,' 'Industries should be required to prove that they safely dispose of dangerous waste materials,' and 'It is important to carry out regular checks on the emissions from cars as a condition of their use.' It was noted that these three strategies were the most discussed by students in this course. For example, in the learning sheet, using recycled paper, some students' statements were presented as follows: 'One of our actions inadvertently affects rainforests so much that I will try my best to cherish this earth' and 'Even if those who deforested were 
Table 4. Means and standard deviations of student responsibility for sustainable development

\begin{tabular}{|c|c|c|c|c|}
\hline Item & Pre-test & Rank & Post-test & Rank \\
\hline $\begin{array}{l}\text { I am in favour of having laws that protect the habitats of endangered } \\
\text { species }\end{array}$ & $3.74(.44)^{\mathrm{a}}$ & 1 & $3.77(.43)$ & 2 \\
\hline $\begin{array}{l}\text { Industries should be required to prove that they safely dispose of } \\
\text { dangerous waste materials }\end{array}$ & $3.72(.51)$ & 2 & $3.79(.41)$ & 1 \\
\hline $\begin{array}{l}\text { It is important to carry out regular checks on the emissions from cars as a } \\
\text { condition of their use }\end{array}$ & $3.67(.48)^{\mathrm{a}}$ & 3 & $3.69(.47)$ & 3 \\
\hline $\begin{array}{l}\text { I am in favour of having laws that regulate factory emissions even if this } \\
\text { would increase the price of products }\end{array}$ & $3.54(.56)$ & 4 & $3.64(.54)$ & 4 \\
\hline To reduce waste, the use of plastic packaging should be kept to a minimum & $3.36(.58)$ & 5 & $3.59(.50)$ & 5 \\
\hline $\begin{array}{l}\text { Electricity should be produced from renewable sources as much as } \\
\text { possible, even if this increases the cost }\end{array}$ & $3.28(.56)$ & 6 & $3.44(.60)$ & 6 \\
\hline $\begin{array}{l}\text { It disturbs me when energy is wasted through the unnecessary use of } \\
\text { electrical appliances }\end{array}$ & $3.13(.70)$ & 7 & $3.36(.63)$ & 7 \\
\hline Overall & $24.44(2.62)$ & & $25.28(2.53)$ & \\
\hline
\end{tabular}

a: Numbers in ( ) are standard deviation

Table 5. Means and standard deviations of student environmental self-efficacy

\begin{tabular}{|c|c|c|c|c|}
\hline Item & Pre-test & Rank & Post-test & Rank \\
\hline $\begin{array}{l}\text { Recognise the science question that underlies a newspaper report on a } \\
\text { health issue }\end{array}$ & $3.08(.70)^{\mathrm{a}}$ & 1 & $3.26(.64)$ & 2 \\
\hline $\begin{array}{l}\text { Explain why earthquakes occur more frequently in some areas than in } \\
\text { others }\end{array}$ & $2.85(.81)$ & 2 & $3.31(.66)$ & 1 \\
\hline Identify the science question associated with the disposal of garbage & $2.85(.71)$ & 2 & $3.18(.60)$ & 4 \\
\hline $\begin{array}{l}\text { Predict how changes to an environment will affect the survival of certain } \\
\text { species }\end{array}$ & $2.77(.78)$ & 4 & $3.08(.74)$ & 5 \\
\hline Identify the better of two explanations for the formation of acid rain & $2.74(.88)$ & 5 & $3.23(.78)$ & 3 \\
\hline Describe the role of antibiotics in the treatment of disease & $2.72(.86)$ & 6 & $2.90(.79)$ & 7 \\
\hline Interpret the scientific information provided on the labelling of food items & $2.69(.86)$ & 7 & $3.08(.70)$ & 5 \\
\hline $\begin{array}{l}\text { Discuss how new evidence can lead to a change in understanding about } \\
\text { the possibility of life on Mars }\end{array}$ & $2.38(.91)$ & 8 & $2.72(.83)$ & 8 \\
\hline Overall & $22.08(4.77)$ & & $24.74(3.99)$ & \\
\hline
\end{tabular}

a: Numbers in ( ) are standard deviation

caught, the officials might cover up the news; therefore, the government must establish a complete law to protect forests.' In the learning sheet, dioxins E burning plastic, one of the students' statements was shown as follows: 'The manufacturing process and the record of discharging schedule of furnace slag should be detailed' and 'The government should legislate to prohibit manufacturers from burning PVC plastic products.' Findings also noted that most of the students' reports about environmental issues at the end of this class were related to air pollution. Students' statements in their report are as follows: 'The government should pay more attention to the seriousness of air pollution and put forward policies to improve air quality, for example, by reducing the number of cars and motorcycles' and 'the Environmental Protection Bureau of Kaohsiung City Government indicated that one of the main causes of haze in Kaohsiung was the gas discharged from cars and motorcycles.'

Despite the fact that these students have already acquired a strong sense of responsibility for sustainable development in the pre-test (mean $=24.44)$, their post-test overall mean score $(25.28)$ was still significantly higher than their pre-test mean $(t=-2.17, p<.001$, effect size $=.33)$ after they were engaged in one semester of SSI discussions.

\section{Self-efficacy for environmental issues}

In the assessment of student self-efficacy for environmental issues, students were asked how easy it was for them to recognize science questions, explain reasons, predict changes, or interpret information for environmental issues. The pre- and post-test means are shown in Table 5. Further dependent t-test of the pre-test $($ mean $=22.08)$ and post-test $($ mean $=24.74)$ indicated that student environmental self-efficacy has been significantly promoted $(t$ $=-4.73, p<.001$, effect size $=.61)$. 
Table 6. Means and standard deviations of student environment-related activities

\begin{tabular}{|c|c|c|c|c|}
\hline Item & Pre-test & Rank & Post-test & Rank \\
\hline Watch TV programs about science, environmental, or ecology & $2.62(.75)^{\mathrm{a}}$ & 1 & $2.82(.79)$ & 1 \\
\hline Visit web sites about science, environmental, or ecology topics & $2.46(.72)$ & 2 & $2.79(.89)$ & 2 \\
\hline $\begin{array}{l}\text { Read science, environmental, or ecology magazines or articles in } \\
\text { newspapers }\end{array}$ & $2.44(.68)$ & 3 & $2.64(.84)$ & 3 \\
\hline $\begin{array}{l}\text { Follow news of science, environmental, or ecology organizations via } \\
\text { blogs and microblogging }\end{array}$ & $2.38(.82)$ & 4 & $2.62(.82)$ & 4 \\
\hline Borrow or buy books on science, environmental, or ecology topics & $2.00(.80)$ & 5 & $2.26(.88)$ & 5 \\
\hline $\begin{array}{l}\text { Listen to radio programs about advances in science, environmental, or } \\
\text { ecology }\end{array}$ & $1.77(.78)$ & 6 & $1.92(.90)$ & 7 \\
\hline Visit web sites of ecology organizations & $1.67(.84)$ & 7 & $2.13(.73)$ & 6 \\
\hline Attend a science, environmental, or ecology club & $1.44(.72)$ & 8 & $1.85(.96)$ & 8 \\
\hline Overall & $16.77(4.29)$ & & $19.03(5.20)$ & \\
\hline
\end{tabular}

a: Numbers in ( ) are standard deviation

\section{Environment-related activities}

Both in the pre- and post-test, students were asked how often they did environment-related activities, such as visiting websites of ecology organisations or watching TV programmes about science, environmental protection, or ecology. The means of their responses with 4 point Likert-scale $(1$ representing never or hardly ever and 4 indicating very often) are shown in Table 6. It can be seen that all of the eight items' post-test means were greater than the corresponding pre-test means. A pair wise t-test result revealed that the students' post-test mean score (19.03) on environment-related activities was significantly higher than the pre-test mean score of $16.77(t=-4.02, p$ $<.001$, effect size $=.48$ ).

\section{How are Student SSI Arguments Varied and Changed over Time?}

Five weekly learning sheets regarding environmental content were collected to analyze students' decisionmaking or standing position and category of argument, including the $2^{\text {nd }}$ week of learning sheet - using recycled paper - the $4^{\text {th }}$ week of learning sheet - importing genetically modified food - the $5^{\text {th }}$ week of learning sheet developing new site for nuclear waste disposal - the $6^{\text {th }}$ week of learning sheet - expanding Meiliwan Resort Hotel - and the $10^{\text {th }}$ week of learning sheet - suspending the Sixth Naphtha Cracking Plant. The details are shown in Table 1.

\section{Changes of student decision-making or standing position}

Students' decision-making or standing position for weekly environmental SSIs shown in Table 1 can be broadly classified into three distinct categories: 'support economic development,' 'compromise economic development and environmental protection,' and 'support environmental protection.' Figure $\mathbf{1}$ reveals that in the beginning of the intervention, there were more students supporting 'economic development' than those supporting 'environmental protection.' For example, according to the results of the $2^{\text {nd }}$ week of learning sheet, the percentage of the students for 'economic development' was 37\%, while that of the students for 'environmental protection' was only $26 \%$. However, in the mid and late stages of the intervention, the gap between the numbers of the students in favour of 'economic development' and those in support of 'environmental protection' became wider. For example, in the $5^{\text {th }}$ week of learning sheet, there were only $3 \%$ of the students supporting 'economic development' while $55 \%$ supporting 'environmental protection'. In the $6^{\text {th }}$ week of learning sheet, there were only $6 \%$ of the students supporting 'economic development,' whereas a majority - $85 \%$ - of the students supported 'environmental protection'. Despite that the percentage of students supporting 'environmental protection' decreased to $65 \%$, there were still $54 \%$ more than those who supported 'economic development'. While it is great to observe that students become more concerned about environmental protections more than economic development, it should be noted that without developing a system that promotes both economic development and environmental protection, it would not be a sustainable solution. It is important that students gain a realistic viewpoint. The decrease of percentage of supporting environmental protection from $85 \%$ to $65 \%$ might be partially attributed to the effect of student realistic viewpoint. 


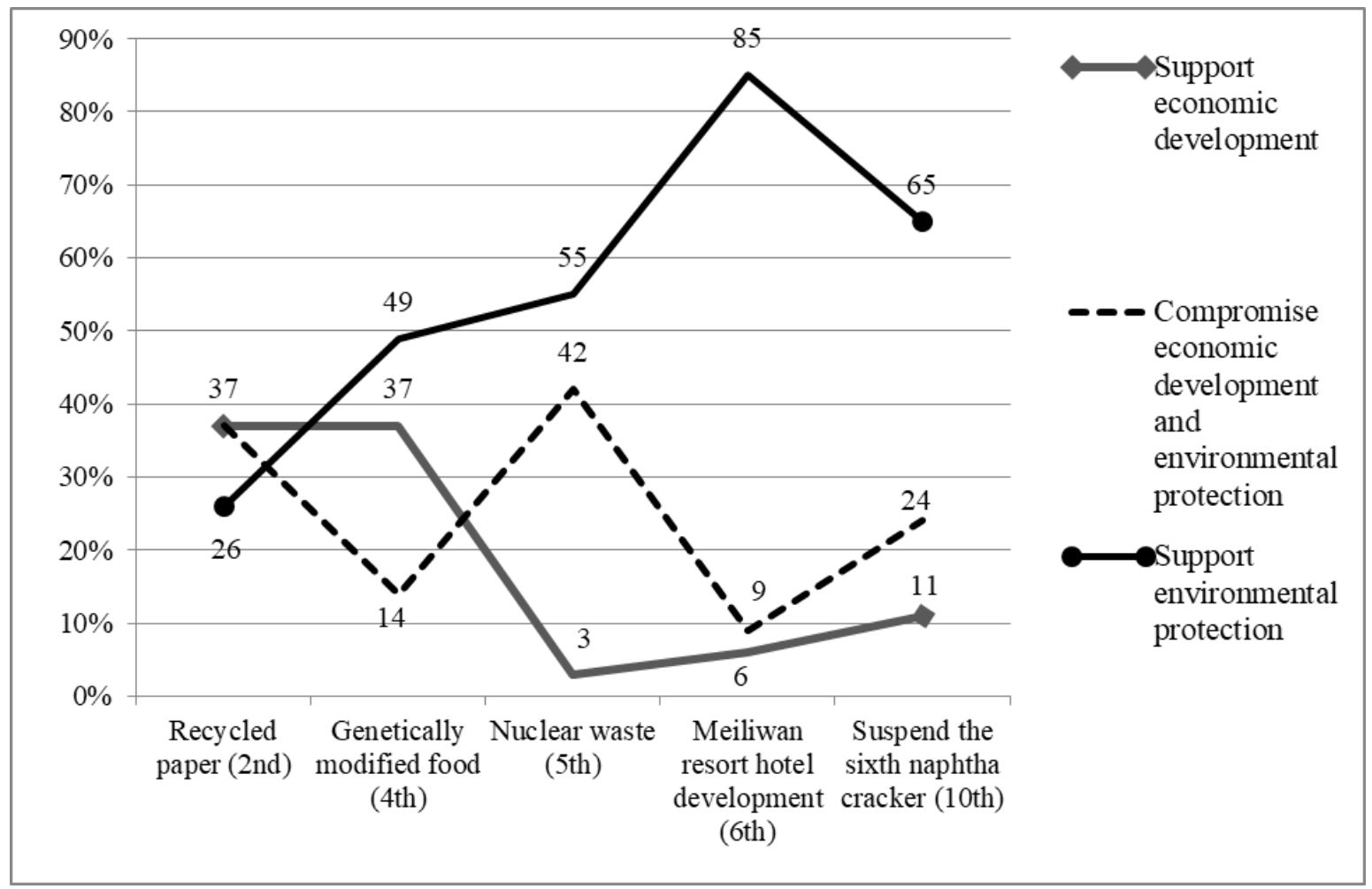

Figure 1. The line graph of student decision-making position in SSI discussions

\section{Changes of student arguments}

The students' arguments in learning sheets included two categories: 'economic development' and 'environmental concern.' Because the students might consider the economic and environmental factors at the same time, the categories of their arguments were expressed by the count of frequency. As shown in Table 7, in the $2^{\text {nd }}$ week, there was no difference between the frequencies of 'economic development' and 'environmental concern.' As the intervention went on to the mid and late phases, more environmental concerns appeared in student arguments. For example, there were only 18 environmental concerns in the students' arguments in the $2^{\text {nd }}$ week; yet, the pro-environment arguments increased to $49,20,37$, and 49 in the $4^{\text {th }}, 5^{\text {th }}, 6^{\text {th }}$, and $10^{\text {th }}$ weeks, respectively. Consequently, according to the results of students' decision-making or standing position and the change of students' arguments, the students attended greater importance on environmental considerations after the SSI discussions. 
Table 7. Student decisions and frequency distribution of arguments in SSI discussions

\begin{tabular}{|c|c|c|c|}
\hline \multirow{2}{*}{ SSI topic } & \multirow{2}{*}{ Student decision } & \multicolumn{2}{|c|}{ Category of argument } \\
\hline & & Economic development & Environmental concern \\
\hline \multirow{4}{*}{ Using recycled paper $\left(2^{\text {nd }}\right)$} & Cons (37\%) & 9 & 1 \\
\hline & Undecided (37\%) & 6 & 10 \\
\hline & Pro (26\%) & 3 & 7 \\
\hline & & $18^{a}$ & 18 \\
\hline \multirow{4}{*}{$\begin{array}{l}\text { Importing genetically modified } \\
\text { food }\left(4^{\text {th }}\right)\end{array}$} & Pro (37\%) & 8 & 5 \\
\hline & Undecided (14\%) & 5 & 10 \\
\hline & Cons (49\%) & 3 & 34 \\
\hline & & 16 & 49 \\
\hline \multirow{4}{*}{$\begin{array}{l}\text { Developing new site for nuclear } \\
\text { waste disposal }\left(5^{\text {th }}\right)\end{array}$} & Pro (3\%) & 0 & 0 \\
\hline & Undecided (42\%) & 0 & 7 \\
\hline & Cons (55\%) & 0 & 13 \\
\hline & & 0 & 20 \\
\hline \multirow{4}{*}{$\begin{array}{l}\text { Expanding Meiliwan resort hotel } \\
\left(6^{\text {th }}\right)\end{array}$} & Pro (6\%) & 2 & 0 \\
\hline & Undecided (9\%) & 1 & 4 \\
\hline & Cons (85\%) & 0 & 33 \\
\hline & & 3 & 37 \\
\hline \multirow{4}{*}{$\begin{array}{l}\text { Suspending the sixth naphtha } \\
\text { cracking factory }\left(10^{\text {th }}\right)\end{array}$} & Pro (11\%) & 4 & 1 \\
\hline & Undecided (24\%) & 3 & 12 \\
\hline & Cons (65\%) & 6 & 36 \\
\hline & & 13 & 49 \\
\hline
\end{tabular}

a: Subtotal of frequency for each SSI topic

\section{DISCUSSION}

The most noteworthy finding of the study is that with one semester of SSI discussions, students' awareness of environmental issues, responsibility for sustainable development, self-efficacy for environmental issues, and environment-related activities have been significantly promoted. A further check of the post-test mean scores of the 23 items $(7,8$, and 8 items for environmental awareness, responsibility of sustainable development, and environmental self-efficacy shown in Tables 3, 4, and 5 responsibility) reveals that these scores are all higher than the pre-test mean scores of their corresponding items. It comes as no surprise that the scores of some items which have been related to the SSI intervention have a significant increase. However, it seems that all items increased in a similar way even if most topics have not been directly taught (e.g., extinction of species). One explanation would be that the students were inspired by the intervention to learn from other resources. Alternatively, it was also possible that the answers of environmental awareness, responsibility of sustainable development, and environment-related activities were socially desired responses. Some of the participants in this study simply responded the way of matching social desirability. It should be careful in interpreting the t-test results as one of the effect sizes (i.e., responsibility for sustainable development) was as small as .33. Although additional studies with larger sample size of students or a comparison group are recommended to confirm its practical utility, the above initial fruitful learning outcome indicates the positive potential effect of using SSI discussions in environmental education at the college level. As mentioned in the literature review, SSI discussions have been rarely used in school courses of environmental education, especially in higher education. The significant effectiveness of this instructional strategy reported in this study can be served to inspire more studies exploring alternative usages.

Another noteworthy finding of the study is that the students' standing positions on environmental socioscientific issues have been changed through the whole process of intervention. Although it is difficult to determine which aspect of the intervention led to the effects, as the health of our planet continues to be impacted by human behaviours, consolidating students' capabilities of building understandings and taking a standing position on socio-scientific issues of local, global or environmental importance would provide an impetus for them to make educated decisions and actions (Birmingham \& Barton, 2014). The intervention of watching contextual video of current environmental issues and SSI discussion provide learning opportunities of argumentation activities, reflection on different perspective arguments, and interaction with peer learners. The argumentation activities of socio-scientific issues entail many different arguments, require the ability to evaluate positions, and provide opportunities for students to practice reflection (Lin et al., 2012). Apart from typical environmental education course focusing on knowledge acquisition, the above activities offered unique opportunities to confront, defend, or reject controversial arguments. Previous studies indicated that the intervention of reflection had significantly positive effect on not only training pre-service science teachers' self-efficacy (Aydeniz \& Ozdilek, 2016), but also 
the professional development of in-service science teachers (Lin et al., 2013). This study extends the merit of applying socio-scientific issue discussions to environmental education and provides insights into how college students' awareness of environmental issues and responsibility for sustainable development can be promoted.

More importantly, the increase of environmental concerns appeared in student written arguments and the changes in their standing position revealed that the whole package of intervention, such as learning activities of confronting, debating, evaluating, and rejecting controversial arguments, was likely to play a critical role in the change. As Ratcliffe and Grace (2003) reminded:

\begin{abstract}
We cannot predict what scientific knowledge, skills or resources will be available to future generations... so the safest, but most difficult, solution at present is to find ways of ensuring the sustainable and equitable utilization of all resources. These solutions will inevitably have to come from a combination of scientific and social endeavours ( $p .11)$.
\end{abstract}

In view of the above arguments, the use of socio-scientific issue discussion in this study provided a platform for students to construct their own responsibility and a better understanding of sustainable development.

Readers were reminded that special attention was focused on designing the teaching of argumentation by use of well-designed and contextualised socio-scientific environmental issues. We were fortunate to have the permission from Taiwan Public Television Service to use its award winning videos of programme - Our Island - for classroom teaching. All of the topics of argumentation were relevant to students' daily life experience. As personal relevance has been identified as one of the key factors related to students' interest in and engagement of learning (Broman \& Simon, 2015; Hashimoto-Martell et al., 2012), the use of personal relevance and video-based contextualised scenarios was more likely to promote students' deep engagement of learning. The follow-up individual work on writing learning sheet and whole class group discussions, along with evaluations and critiques on peers' divergent arguments, provided opportunities for students to reflect on their own arguments and elaborate for a better and educated decision-making. In addition, readers were reminded that an introduction of related theories and scientific concepts was required before the contextualised videos of SSI were presented. The background knowledge has potential to enable students' better understanding of the SSI and provide opportunities for them to go into depth while they are preparing and evaluating arguments. Previous studies have confirmed that engagement in learning science has a significant and synergistic effect on environmentalism (e.g., Jack et al., 2014; Pan et al., 2018). The results of this study allow us further understand what teaching activities are effective in empowering students' learning engagement.

\title{
LIMITATION
}

While this study provides strong evidence for the potential advantage of using SSI in environmental education, there are limitations that should be addressed in future studies.

First, the change of the students' environmental awareness, responsibility for sustainable development, selfefficacy for environmental issues, and environment-related activities reported in this study might not totally result from the SSI discussion and intervention. For example, it was likely that the positive change of students' environmentalism was their perception of matching expectations of the course intervention. In addition, the students may have learned from television, internet, or newspaper report on the social issue that the aboriginal people of Orchid Island protested against the government and Taiwan Power Company in the capital city, demanding the removal of nuclear waste from their small island owing to the expiration of the rental contract between the local government and the power company. The voices of the aboriginal people and the statements of environmental activists disseminated by the above media might have contributed to the change in students' attitude toward and standing position of nuclear waste treatment. Based on our knowledge, the above media report of nuclear waste is a one-time incident that may impact student environmentalism.

Second, despite the facts that we have collected both quantitative and qualitative data to check what type of student environment-related viewpoints and activities have been changed, these positive results of this study may not be generalisable to other forms of applying SSI instruction to environmental education. Previous studies have recommended that essential parts of reflection have to be integrated in instructing complex decision-making strategies (Böttcher \& Meisert, 2013). In addition, Gresch, Hasselhorn, and Bögeholz (2017) asserted that the quality of student decision-making process could be effectively enhanced by the training of reflection practice. Future research studies are encouraged to explore how students' standing position on environmental socio-scientific issues is influenced by the teaching intervention of reflection especially at the higher education level, since most of the students will be leaders or active members of future society, and further to explore the practical utility of other forms of SSI discussions. 
Third, we have only collected students' learning sheets to analyze their decision-making (or standing position) and the theme of their arguments. In order to make in-depth analysis, future studies are encouraged to investigate the process and related skills of students' argumentation through audio and video recording.

\section{CONCLUSION}

The quantitative results of this study provided original insights into the effect of SSI discussions on promoting the university students' awareness of environmental issues, responsibility for sustainable development, selfefficacy for environmental issues, and environment-related activities. The qualitative findings also highlighted how the students developed decision-making and standing position through reflecting and evaluating classmate arguments and comments during the discussion of SSI.

While Huckle (1991) posited that the merits and complexities of sustainable development should continue to be contested, Jickling (1992) further asserted that educators should 'enable students to debate, evaluate, and judge for themselves the relative merits of contesting positions' (p. 8), instead of simply indoctrinating them for sustainable development through teaching courses. It is suspected that the process of reflecting on, evaluating, and responding to peers' comments, critiques, challenges, and suggestions may be a catalyst that helps the student engage in the development of divergent and convergent thinking skills of planning and elaborating strategies for solving the problems of environmental issues. Therefore, for those teachers who already have crowded curriculum but are interested in teaching environmentalism, the video-based argumentation of SSI along with interactive peer evaluation and discussion teaching strategies would be highly recommended.

This study successfully adds to our understanding of environmental and sustainability education, helping to empower individual citizens to develop critical thinking and competence of taking part actively in democratic process on environmental and sustainability issues. Additional research is needed to confirm the mechanism and the role of the above activities on changing students' standing position of environmental socio-scientific issues.

\section{ACKNOWLEDGEMENTS}

This study was supported by the Ministry of Science and Technology, Taiwan under the grant of MOST 1052511-S-110-001-MY4.

\section{REFERENCES}

Aikenhead, G. S. (1994). What is STS science teaching? In J. Solomon \& G. Aikenhead (Eds), STS education: International perspectives in reform. (pp. 47-59). New York: Teachers College Press.

Aydeniz, M., \& Ozdilek, Z. (2016). Assessing and enhancing pre-service science teachers' self-efficacy to teach science through argumentation: Challenges and possible solutions. International Journal of Science and Mathematics Education, 14(7), 1255-1273. https:/ / doi.org/10.1007/s10763-015-9649-y

Belova, N., Eilks, I., \& Feierabend, T. (2015). The evaluation of role-playing in the context of teaching climate change. International Journal of Science and Mathematics Education, 13(1), 165-190. https://doi.org/10.1007/s10763013-9477-x

Birmingham, D., \& Barton, A. C. (2014). Putting on a green carnival: Youth taking educated action on socioscientific issues. Journal of Research in Science Teaching, 51(3), 286-314. https:/ / doi.org/10.1002/ tea.21127

Blum, N., Nazir, J., Breiting, S., Goh, K. C., \& Pedretti, E. (2013). Balancing the tensions and meeting the conceptual challenges of education for sustainable development and climate change. Environmental Education Research, 19(2), 206-217. https:/ / doi.org/10.1080/13504622.2013.780588

Böttcher, F., \& Meisert, A. (2013).Effects of direct and indirect instruction on fostering decision-making competence in socioscientific issues. Research in Science Education, 43, 479-506. https:/ / doi.org/10.1007/s11165-011-92710

Boubonari, T., Markos, A., \& Kevrekidis, T. (2013). Greek pre-service teachers' knowledge, attitudes, and environmental behavior toward marine pollution. Journal of Environmental Education, 44, $232-251$. https:/ / doi.org/10.1080/00958964.2013.785381

Broman, K., \& Simon, S. (2015). Upper secondary school students' choice and their ideas on how to improve chemistry education. International Journal of Science and Mathematics Education, 13(6), 1255-1278. https:/ / doi.org/10.1007/s10763-014-9550-0

Christenson, N., Chang Rundgren, S., \& Zeidler, D. L. (2014). The relationship of discipline background to upper secondary students' argumentation on socioscientific issues. Research in Science Education, 44, 581-601. https:/ / doi.org/10.1007/s11165-013-9394-6 
De Haan, G. (2006). The BLK '21' programme in Germany: A 'Gestaltungskompetenz'-based model for education for sustainable development. Environmental Education Research, 12(1), 19-32. https:/ / doi.org/10.1080/13504620500526362

Dewey, J., \& Bentley, A. F. (1949). Knowing and the known. Boston: Beacon Press.

Driver, R., Leach, J., Millar, R., \& Scott, P. (1996). Young people's images of science. Buckingham: Open University Press.

Dunlap, R., \& Van Liere, K. (1978). The "new environmental paradigm": A proposed measuring instrument and preliminary results. Journal of Environmental Education, 9(4), 10-19. https:/ / doi.org/10.1080/00958964.1978.10801875

Dunlap, R., Van Liere, K., Mertig, A., \& Jones, R. (2000). Measuring endorsement of the new ecological paradigm: A revised NEP scale. Journal of Social Issues, 56, 425-442. https:/ / doi.org/10.1111/0022-4537.00176

Englund, T. J., Öhman, J., \& Öhman, L. (2008). Deliberative communication for sustainability: A Habermas-inspired pluralistic approach. In S. Gough \& A. Stables (Eds), Sustainability and Security within Liberal Societies (pp. 2948). London: Routledge.

Gadotti, M. (2008). What we need to learn to save the planet. Journal of Education for Sustainable Development, 2(1), 21-30. https:// doi.org/10.1177/097340820800200108

Gresch, H., Hasselhorn, M., \& Bögeholz, S. (2017). Enhancing decision-making in STSE education by inducing reflection and self-regulated learning. Research in Science Education, 47(1), 95-118. https:/ / doi.org/10.1007/s11165-015-9491-9

Hashimoto-Martell, E. A., McNeill, K. L., \& Hoffman, E. M. (2012). Connecting urban youth with their environment: The impact of an urban ecology course on student content knowledge, environmental attitudes and responsible behaviors. Research in Science Education, 42(5), 1007-1026. https:/ / doi.org/10.1007/s11165-0119233-6

Huckle, J. (1991). Education for sustainability: Assessing pathways to the future. Australian Journal of Environmental Education, 7, 43-62. https:/ / doi.org/10.1017/S0814062600001853

Huckle, J. (2008). An analysis of new labour's policy on education for sustainable development with particular reference to socially critical approaches. Environmental Education Research, 14(1), 65-75. https:// doi.org/10.1080/13504620701843392

Jack, B., Lin, H. S., \& Yore, L. (2014). The synergistic effect of affective factors on student learning outcomes. Journal of Research in Science Teaching, 51(8), 1084-1101. https:/ / doi.org/10.1002/tea.21153

Jickling, B. (1992). Why I don't want my children to be educated for sustainable development. Journal of Environmental Education, 23(4), 5-8. https:/ / doi.org/10.1080/00958964.1992.9942801

Læssøe, J. (2010). Education for sustainable development, participation and socio-cultural change. Environmental Education Research, 16(1), 39-57. https:// doi.org/10.1080/13504620903504016

Landis, J. R., \& Koch, G. G. (1977). The measurement of observer agreement for categorical data. Biometrics, 33(1), 159-174. https:/ / doi.org/10.2307/2529310

Lin, H. S., Hong, Z. R., \& Lawrenz, F. (2012). Promoting and scaffolding argumentation through reflective

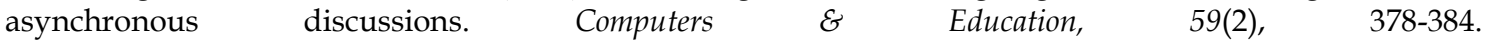
https:// doi.org/10.1016/j.compedu.2012.01.019

Lin, H. S., Hong, Z. R., Yang, K. K., \& Lee, S. T. (2013). The impact of collaborative reflections on teachers' inquiry teaching. International Journal of Science Education, 35(18), 3095-3116. https:/ / doi.org/10.1080/09500693.2012.689023

McNeill, K. L., \& Vaughn, M. H. (2012). Urban high school students' critical science agency: Conceptual understandings and environmental actions around climate change. Research in Science Education, 42(2), 373399. https:/ / doi.org/10.1007/s11165-010-9202-5

Mogensen, F., \& Schnack, K. (2010). The action competence approach and the 'New' discourses of education for sustainable development, competence and quality criteria. Environmental Education Research, 16(1), 59-74. https:/ / doi.org/10.1080/13504620903504032

Morelli, J. (2011). Environmental sustainability: A definition for environmental professionals. Journal of Environmental Sustainability, 1(1), 1-10. https:// doi.org/10.14448/jes.01.0002

OECD (2009). PISA 2006 technical report. Paris: OECD Publishing. Retrieved from https://www.oecd.org/pisa/data/42025182.pdf

OECD (2016). PISA 2015 assessment and analytical framework: Science, reading, mathematics and financial literacy. Paris: OECD Publishing. http:/ / dx.doi.org/10.1787/9789264255425-en. 
Öhman, J., \& Öhman, M. (2013). Participatory approach in practice: An analysis of student discussions about climate change. Environmental Education Research, 17(3), 324-341. https:/ / doi.org/10.1080/13504622.2012.695012

Pan, Y. T., Yang, K. K., Hong, Z. R., \& Lin, H. S. (2018). The effect of interest and engagement in learning science on adults' scientific competency and environmental action. EURASIA Journal of Mathematics, Science and Technology Education, 14(12), em1609. https:/ / doi.org/10.29333/ ejmste/94225

Pedretti, E. (2003). Teaching science, technology, society and environment education. In D. L. Zeidler (Ed), The role of moral reasoning in socio-scientific issues and discourse in science education (pp. 218-238). London: Kluwer Academic Publishers. https:/ / doi.org/10.1007/1-4020-4996-X_12

Ratcliffe, M., \& Grace, M. (2003). Science education for citizenship: Teaching socio-scientific issues. Milton Keynes: Open University Press.

Sadler, T. D. (2004). Informal reasoning regarding socioscientific issues: A critical review of research. Journal of Research in Science Teaching, 41(5), 513-536. https:/ / doi.org/10.1002/tea.20009

Sadler, T. D., \& Dawson, V. (2012). Socioscientific issues in science education: Contexts for the promotion of key learning outcomes. In B. J. Fraser, K. G. Tobin, \& C. J. McRobbie (Eds.), Second International Handbook of Science Education: Part Two (pp. 799-809). The Netherlands: Springer. https://doi.org/10.1007/978-1-40209041-7_53

Sadler, T. D., \& Donnelly, L. (2006). Socioscientific argumentation: The effects of content knowledge and morality. International Journal of Science Education, 28(12), 1463-88. https:/ / doi.org/10.1080/09500690600708717

Schnack, K. (2000). Action competence as a curriculum perspective. In B. B. Jensen, K. Schnack, \& V. Simovska (Eds), Critical environmental and health education - Research issues and challenges (pp. 107-126). Copenhagen: The Danish University of Education.

Schultz, J. R. (2011). The environmental action and philosophy matrix: An exploratory study of the environmental attitudes of recreation management and environmental studies students. Journal of Environmental Education, 42(2), 98-108. https:/ / doi.org/10.1080/00958964.2010.507637

Sternäng, L., \& Lundholm, C. (2012). Climate change and costs: Investigating Chinese students' conceptions of nature and economic development. Environmental Education Research, 18, 417436. https: / / doi.org/10.1080/13504622.2011.630532

Tabachnick, B. G., \& Fidell, L. S. (2001). Using multivariate statistics. Boston: Allyn and Bacon.

Venville, G. J., \& Dawson, V. M. (2010). The impact of a classroom intervention on grade 10 students' argumentation skills, informal reasoning, and conceptual understanding of science. Journal of Research in Science Teaching, 47(8), 952-977. https:/ / doi.org/10.1002/tea.20358

Wilks, L., \& Harris, N. (2016). Examining the conflict and interconnectedness of young people's ideas about environmental issues, responsibility and action. Environmental Education Research, 22(5), 683-696. https:/ / doi.org/10.1080/13504622.2015.1054261

Yahaya, J. M., Zain, A. N. N., \& Karpudewan, M. (2015). The effects of socio-scientific instruction on pre-service teachers' sense of efficacy for learning and teaching controversial family health issues. International Journal of Science and Mathematics Education, 13(2), 467-491. https:/ / doi.org/10.1007/s10763-014-9537-x

Yu, S. M., \& Yore, L. D. (2013). Quality, evolution, and positional change of university students' argumentation patterns about organic agriculture during an argument-critique-argument experience. International Journal of Science and Mathematics Education, 11(5), 1233-1254. https:/ / doi.org/10.1007/ s10763-012-9373-9

Zeidler, D. L., Osborne, J., Erduran, S., Simon, S., \& Monk, M. (2003). The role of argument during discourse about socioscientific issues. In D. L. Zeidler (Ed.), The role of moral reasoning on socioscientific issues and discourse in science education (pp. 97-116). Netherland: Kluwer Academic Publishers. https://doi.org/10.1007/1-40204996-X_6

\section{http://www.ejmste.com}

